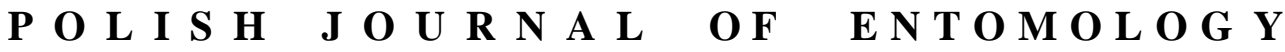

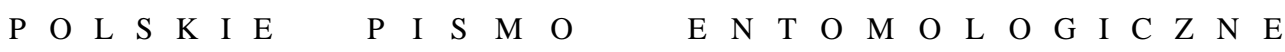

VOL. 86: $3-8$

Lublin

31 March 2017

DOI: $10.1515 /$ pjen-2017-0001

\section{In memoriam - Yuri Aleksandrovicz PoPOV}

\author{
AleKSANDER HERCZEK*, PiOTR WEGIEREK \\ Department of Zoology, University of Silesia in Katowice, Bankowa 9, \\ 40-007 Katowice, Poland
}

On $16^{\text {th }}$ November 2016, Yuri Alexandrovich POPOV, the world-renowned palaeontologist passed away. His specialisms were the morphology, taxonomy and phylogeny of insects, particularly Heteroptera and Coleorrhyncha. His work was devoted to both modern and fossil insects.

Yuri Alexandrovich PoPOV was born in Moscow, Russia, on $5^{\text {th }}$ March, 1936. In 1959 he graduated from Moscow State University, Faculty of Biology, Chair of Entomology. After 1959 Yuri worked at the Palaeontological Institute of the Russian (formerly Soviet) Academy of Sciences (RAS) in the Arthropod Laboratory, holding the posts of senior technical worker, junior research worker (1961-1971), secretary of the international scientific connection in the Presidium of the Academy of Sciences of the USSR (19711975), and senior research worker (since 1981). He was Professor (Senior Scientific Research) and Curator at the Zoological Museum of Moscow State University, with the Heteroptera suborder as his main field .

His cooperation with Polish scientists began in 1964 when he met the well-known Polish entomologist, Professor Sędzimir Maciej KLIMASZEWSKI, who was at that time visiting the Laboratory of Arthropods of the Palaeontological Institute of the USSR Academy of Sciences. As a result of their lively discussions and ever closer cooperation, both specialists in hemipteran insects became good friends and remained so until Professor KLIMASZEWSKI's death. In 1969 Yuri spent six months at the Zoological Institute of Warsaw working on the systematics and morphology of water bugs of the Institute's collection. That visit was part of the inter-academic agreement between the Polish

\footnotetext{
* Corresponding author: aleksander.herczek@us.edu.pl
} 


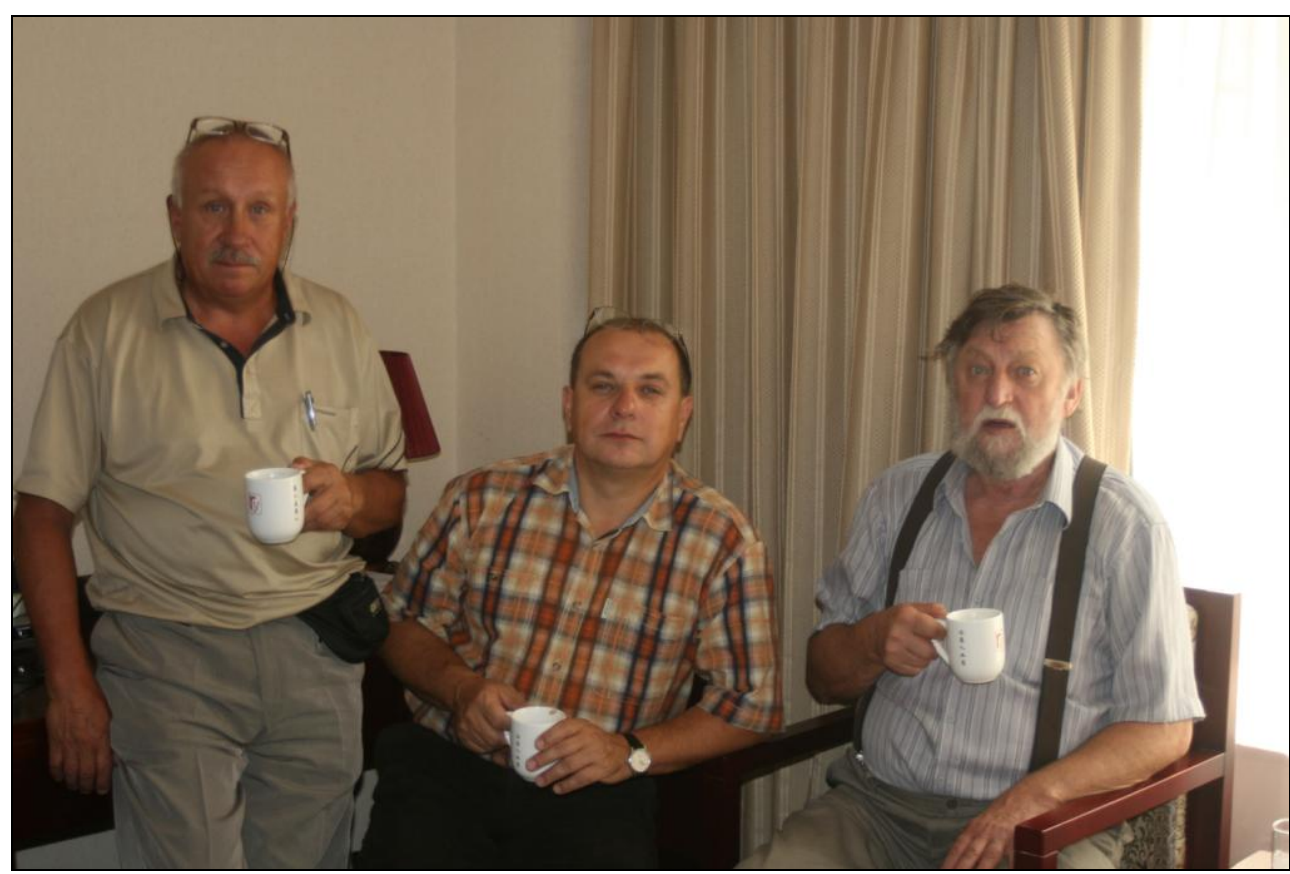

Aleksander HERCZEK, Piotr WĘGIEREK and Yuri POPOV. The $5^{\text {th }}$ International Conference of Fossil Insects in China (Beijing, 2010)

Academy of Sciences and the USSR Academy of Sciences. Professor Tadeusz JACZEWSKI, an eminent hemipterologist, who had a significant influence on systematic and morphological views regarding water bugs of the Nepomorpha infra-order, helped Yuri in the study of this group of insects. During that first visit he also made the acquaintance of Professor Henryk SzELEGIEwICZ, a well-known specialist in Aphidoidea (Hemiptera). The next visit was to Lublin University at the invitation of Professor KLIMASZEWSKI, who showed Yuri how his Laboratory was run.

The 1970s and 1980s were a period of Yuri's intense research on Mesozoic hemipteran fauna and the phylogeny of their groups. At that time his first publications appeared on bugs from Baltic (POPOV 1978, CARVALHO \& POPOV 1984) and Dominican (POPOV 1987, 1989) amber. That new interest in the Heteroptera in Eocene Baltic amber led Yuri in early 1980 to the Museum of the Earth of the Polish Academy of Sciences with its extensive collection of such amber. There he established close scientific and friendly contacts with the curators of this collection, Professor Barbara KOSMOWSKA-CERANOWICZ and Dr Róża KULICKA. These contacts and friendship continued until his death. The early 1990s were the start of Yuri's "amber period", which continued until his death. His publications from 
that time yielded information on new taxa of Heteroptera preserved in the world's amber. He wrote the majority of articles in collaboration with colleagues: A. HERCZEK (Miridae, Anthocoridae and Microphysidae), V.B. Golub (Tingidae) and P.V. PUTSHKOV (Reduviidae). It was during this period that Yuri's long-term, close and productive collaboration with the Department of Zoology and mainly with Professor Aleksander HERCZEK (Silesian University, Katowice) began.

For many years Yuri received invaluable assistance in studying fossil material (both amber and stone remains) from the world-famous hemipterologist Professor Jan KOTEJA (Kraków), a good friend and colleague of the Russian palaeontologists from the RAS Laboratory of Arthropods. Close collaboration also continued for many years with colleagues from Kraków, Professor Wiesław KRZEMIŃsKI and Professor Ewa KRZEMIŃsKA (the Institute of Systematics and Evolution of Animals, PAS, Kraków). The collection of materials from the Museum and the Arthropod Laboratory were jointly used in some publications.

In the taxonomic field he was the author of three new heteropteran infraorders (Nepomorpha, Gerromorpha and Leptopodomorpha), 8 families, 12 subfamilies, 15 tribes, over 100 genera and nearly 200 fossil and recent species. He published more than 150 articles and book chapters on the above groups, as well as a monograph on water bugs.

In the last twenty years Yuri regularly participated in the cyclic international meetings (“Amberif") in Gdańsk, where specialists in organic remains (mainly insects) in Baltic amber meet, sell and identify the contents of inclusions as well as hold scientific seminars given over to amber. These are followed by publications in special issues of the journal of the Museum of Gdańsk University (Prof. Ryszard SzADIEWSKI and Dr Elżbieta SONTAG) and the Museum of the Earth (Prof. Barbara KosmowsKa-CERANOwICZ) "Bursztynisko".

The period of collaboration with Polish scientists bore fruit in the form of some fifty coauthored publications, which significantly contributed to Yuri's achievements.

There is no doubt that in saying our final farewell to Yuri the worldwide community of entomologists has lost an eminent specialist, a charming companion and a friendly colleague. He will always remain in our memories.

\section{Bibliography of Yuri A. POPOV's publications in Polish journals or in collaboration with Polish scientists}

1. Popov Yu.A. 1970. Notes on the classification of the recent Naucoridae (Heteroptera, Nepomorpha). Bulletin de L'Academie Polonaise des Sciences, Série des Sciences Biologiques, CI. II 18(2): 93-98.

2. Popov Yu.A. 1978. New species of Aradidae (Hemiptera) from the Baltic amber. Prace Muzeum Ziemi 29: 137-140. 
3. Herczer A., Popov Yu.A. 1992. A remarkable Psallopinous bug from Baltic amber (Insecta: Heteroptera, Miridae). Mitteilungen aus dem Geologisch-Paläontologischen Institut der Universität Hamburg 73: 235-239.

4. Popov Yu.A., HerczeK A. 1992. The first Isometopinae from Baltic amber (Insecta: Heteroptera, Miridae). Mitteilungen aus dem Geologisch-Paläontologischen Institut der Universität Hamburg 73: $241-258$.

5. Popov Yu.A. 1993. A new genus of Emesinae from Dominican amber (Heteroptera: Reduviidae). Acta Zoologica Cracoviensia 35(3): 435-443.

6. Popov Yu.A. 1993. New data on Heteroptera in amber resins. Annals of the Upper Silesian Museum (Entomology) Suppl. 1: 7-12.

7. Kuimaszewski S.M., Popov Yu.A. 1993. New fossil Hemipteran insects from southern England (Hemiptera: Psyllina+Coleorrhyncha). Annals of the Upper Silesian Museum ( Entomology) Suppl. 1: 13-36.

8. Popov Yu.A., HerczeK A. 1993. Metoisops puctatus sp.n., the second represantative of fossil genus Metoisops from Baltic amber (Heteroptera: Miridae: Isometopinae). Annals of the Upper Silesian Museum (Entomology) Suppl. 1: 51-56.

9. Popov Yu.A. 1994. Notes On the little known species of the genus Empicoris WolfF (Heteroptera: Reduviidae: Emesinae). Genus 5(4): 349-355.

10. Popov Yu.A. 1996. The first record of a fossil water bug from the lower jurassic of poland (Heteroptera: Nepomorpha: Belostomatidae). Polskie Pismo Entomologiczne 65(3-4): 101-105.

11. Kulicka R., Herczek A., Popov Yu.A. 1996. Heteroptera in the Baltic amber. Prace Muzeum Ziemi 44: 19-23.

12. Herczek A., Popov Yu.A. 1997. On the mirid genera Archeofulvius Carvalho and Balticofulvius N.gen. from the Baltic amber (Heteroptera: Miridae, Cylapinae). Mitteilungen aus dem Geologisch-Paläontologischen Institut der Universität Hamburg 80: 179-187.

13. HerczeK A., Popov Yu.A. 1997. New peculiar representatives of the Isometopinae from the Baltic amber (Heteroptera: Miridae). Mitteilungen aus dem Geologisch-Paläontologischen Institut der Universität Hamburg 80: 189-195.

14. Herczer A., Popov Yu.A. 1998. Plant bugs from the Late Cretaceous of the north-eastern Siberia (Heteroptera, Miridae). Acta Biologica Silesiana 32(49): 38-49.

15. HerczeK A., Popov Yu.A. 1998. Epigonomiris skalskii n.gen. n.sp., a new Mirinae plant bug from Baltic amber (Heteroptera: Miridae: Cylapinae). Polskie Pismo Entomologiczne 67(3-4): $175-178$.

16. HerczeK A., Popov Yu.A. 1999. On plant bugs from the Baltic amber (Heteroptera: Miridae, Cylapinae) Based On The Old Type Species. Mitteilungen aus dem GeologischPaläontologischen Institut der Universität Hamburg 83: 249-262.

17. Herczek A., Popov Yu.A., Peñalver E. 2000. The first record of Cylapinous plant bugs from the Lower Miocene of Spain: Aragocylapus miocaenicus n.gen., n.sp. (Heteroptera: Miridae, Cylapinae). [in:] X. Martinez-Delclòs, A. Nel (eds.). Studies on mesozoic and Tertiary insects. Systematics, Phylogeny and Taphonomy. Acta Geologica Hispanica 35(1-2): 183-188.

18. Herczek A., Popov Yu.A. 2000. Ambocylapus kulickae gen. et sp., a new plant bug from the Baltic amber (Heteroptera: Miridae, Cylapinae). Polskie Pismo Entomologiczne 69(2): 155-160.

19. Popov Yu.A., HerczeK A. 2001. A new flower bug (Hemiptera: Heteroptera, Anthocoridae) from the Baltic amber. Prace Muzeum Ziemi 46: 55-58. 
20. HerczeK A., Popov Yu.A. 2001. Redescription of the oldest plant bugs from the Upper Jurassic of the southern Kazakhstan (Heteroptera: Cimicomorpha, Miridae). Annals of the Upper Silesian Museum (Entomology) 10-11: 121-128.

21. HerczeK A., Popov Yu.A. 2001. A short review of fossil plant bugs (Heteroptera: Miridae). Annals of the Upper Silesian Museum (Entomology) 10-11: 26-27.

22. Golub V.B., Popov Yu.A. 2003. The new fossil genus of Vianaididae (Heteroptera: Tingoidea) from the Cretaceous amber of New Jersey; evolution of the family in the Late Cretaceous. Acta Zoologica Cracoviensia 46 (Suppl. Fossil Insects): 109-116.

23. Putshrov P.V., Popov Yu.A. 2003. The first find of Microphysidae from the Rovno amber (Heteroptera, Cimicomorpha). Annals of the Upper Silesian Museum 12: 81-85.

24. Popov Yu.A., HerczeK A. 2003. Another new plant bug from Baltic amber (Heteroptera: Miridae, Cylapinae). Annals of the Upper Silesian Museum (Entomology) 12: 111-115.

25. Popov Yu.A. 2004. New Microphysids (Heteroptera: Cimicomorpha, Microphysidae) from baltic Amber and taxonomy of this family. Prace Muzeum Ziemi 47: 97-107.

26. HerczeK A., Popov Yu.A. 2005. New Cylapinae plant bugs (Heteroptera: Miridae, Cylapinae) from Baltic amber. Polskie Pismo Entomologiczne 74(3): 299-307.

27. HerczeK A., Popov Yu.A., Kania I. 2005. A new find of a peculiar Cylapinae bug (Hemiptera: Heteroptera, Miridae) from the Eocene Baltic amber. Annals of the Upper Silesian Museum (Entomology) 13: 81-86.

28. Popov Yu.A., HerCZEK A. 2006. Cylapopsallus kerzhneri gen. et sp.n. - a new peculiar mired from baltic amber. Russian Entomological Journal 15(2): 187-188.

29. Herczek A., Popov Yu.A. 2006. New Isometopinae fron the Oriental and Australian Regions (Heteroptera: Miridae). Polskie Pismo Entomologiczne 75(2): 267-276.

30. Popov Yu.A., HerczeK A. 2008. A short review of fossil plant bugs, with check-list of extinct mirids (Heteroptera: Cimicomorpha, Miridae). Prace Muzeum Ziemi, 49: 59-72.

31. Popov Yu.A., HerczeK A., KANiA J. 2008. One more microphysid (Heteroptera: Cimicomorpha, Microphysidae) from the Eocene Baltic amber. Genus 19(4): 611-617.

32. HerczeK A., Popov Yu.A. 2009. New plant bugs (Insecta, Hemiptera, Heteroptera, Miridae) from the Eocene Baltic amber. Denisia 26, N.S. 86: 93-98.

33. Popov Yu.A., HerczeK A. 2009. A new peculiar minute bug (Hemiptera, Heteroptera, Cimicomorpha, Microphysidae) from the Eocene baltic amber. Denisia 26, N.S. 86: 151-154.

34. HerczeK A., Popov Yu.A. 2010. A short review of fossil Psallopinous bugs (Hemiptera: Heteroptera, Miridae, Psallopinae) in the Eocene Baltic amber. [in:] Program and abstracts. The $5^{\text {th }}$ International Conference on. Fossil Insects, Arthropods and Amber, Beijing, China, August 20-25, 2010. Capital Normal University, Beijing, 136-138.

35. Herczek A., Popov Yu.A., Brożek J. 2010. New plant bugs of the tribe Hallodapini (Heteroptera: Miridae: Phylinae) from the Eocene Baltic amber. Annales Zoologici 60(4): 583-588.

36. Popov Yu.A., Herczek A., BrożeK J. 2011. J The first fossil Dufoueillini (Hemiptera: Heteroptera: Anthocoridae: Lyctocorinae) from the Eocene Baltic amber. Zootaxa 2760: 53-60.

37. HerczeK A., Popov Yu.A. 2011. New Isometopinae (Hemiptera: Heteroptera: Miridae) from the Oriental Region, with some notes on the genera Alcecoris and Sophianus. Zootaxa 3023: 43-50.

38. Popov Yu.A., HerCZEK A., BrożeK J. 2011. Brachypicritus ribesi n. gen., n. sp., a new fossil Cardiastethini (Hemiptera: Heteroptera: Anthocoridae) from the Eocene Baltic amber. Heteropterus Revista de Entomología 11(2): 323-327. 
39. Popov Yu.A., Kosmowska-Ceranowicz B., Herczek A., Kupryjanowicz J. 2011. Review of true bugs (Insecta: Hemiptera, Heteroptera) from the amber collection of the Museum of the Earth of PAS in Warsaw with some remarks on heteropteran insects from Eocene European amber. Polish Journal of Entomology 8(4): 699-728.

40. HerczeK A., Popov Yu.A. 2012. A new peculiar isometopine genus (Hemiptera: Heteroptera: Miridae) from the Eocene Baltic amber. Zootaxa 3196: 64-68.

41. Herczer A., Popov Yu.A. 2012. A short review of fossil Psallopinae (Hemiptera: Heteroptera, Miridae). [in:] Sixth European Hemiptera Congress, 25-29 June 2012, Blagoevgrad, Bulgaria. Programme and Abstracts. Pensoft, Sofia - Moscow, 54-55.

42. Herczer A., Popov Yu.A. 2013. About some fossil mirids from the peculiarity subfamily Psallopinae (Hemiptera: Heteroptera, Miridae). [in:] $6^{\text {th }}$ International Congress on Fossil Insects, Arthropods and Amber. 14-18 April 2013. Abstract book. Byblos, Lebanon, 80-81.

43. Herczek A., Popov Yu.A., Perkovsky E.E. 2013. Another new representative of the isometopine genus Archemyiomma (Hemiptera: Heteroptera: Miridae) from Late Eocene Rovno (Ukraine) amber. [in:] D. AZAR, M.S. Engel, E. JARZEMbOwSKy, A. Nel, J. SANTIAGo-Blay (eds.). Insect Evolution in an Amberiferous and Stone Alphabet. Proceedings of the $6^{\text {th }}$ International Congress on Fossil Insects, Arthropods and Amber. Brill, Leiden, Boston, 47-54.

44. HerczeK A., Popov Yu.A, 2014. New psallopinous plant bugs (Hemiptera: Heteroptera, Miridae, Psallopinae) from the New Hebrides and Nigeria. Zootaxa 3878: 366-378.

45. HerczeK A., Popov Yu.A. 2014. Revision of the genus Metoisops (Hemiptera: Heteroptera, Miridae, Isometopinae) from late Eocene European amber. Zootaxa 3887: 401-421.

46. HerczeK A., Popov Yu.A. 2015. An unusual new species of Hallodapomimus HerczeK, 2000 from the Eocene Baltic amber (Hemiptera, Heteroptera, Miridae, Phylinae). ZooKeys 489: 25-32.

47. Herczer A., Popov Yu.A. 2015. About some fossil mirids from the peculiar subfamily Psallopinae (Hemiptera: Heteroptera, Miridae). Bursztynisko 37: 29-30.

48. Popov Yu.A., ChŁond D. 2015. The first fossil record of the Emesinae genus Emesopsis UhleR (Hemiptera: Heteroptera, Reduviidae) from Eocene Baltic amber. Zootaxa 4039: 566-574.

49. Herczer A., Popov Yu.A., Gorczyca J. 2015. First new fossil plant bugs of the genus Psallops UsIngER, 1946 (Hemiptera: Heteroptera, Miridae, Psallopinae) from the Eocene Baltic amber. Zootaxa 4052: 495-500.

50. HerczeK A., Popov Yu.A., Gorczyca J. 2016. A new Psallopine plant bug from Ghana (Hemiptera: Heteroptera: Miridae: Psallopinae). Entomologica Americana 122(1-2): 164-168.

51. Herczer A., Popov Yu.A., Gorczyca J. 2016. Psallops niedzwiedzkii, a new species from Ghana with a key to African species (Heteroptera, Miridae, Psallopinae). ZooKeys 603: 161-169.

Received: 7 February 2017

Accepted: 7 February 2017 